Dr RADE RISTANOVIĆ, naučni saradnik

Institut za savremenu istoriju

Beograd, Republika Srbija

UDK 94(497.11 Београд)"1941/1944"(093.2)

raderistanovic@hotmail.com

323.23:654.19(497.11)"1941"(093.2)

originalan naučni rad / original scientific paper

primljeno / received: 4. 12. 2019.

prihvaćeno / accepted: 20. 5. 2020.

https://doi.org/10.29362/ist20veka.2020.2.ris.103-128

\title{
VERBALNI DELIKT, BEOGRAĐANI I OKUPACIONI REŽIM TOKOM DRUGOG SVETSKOG RATA
}

APSTRAKT: Ukidanje slobode govora i zabrana prikupljanja informacija koje ne potiču iz zvaničnih izvora bili su deo mera koje je okupator sprovodio u nameri da pacifikuje okupirani prostor $i$ obeshrabri pružanje otpora na teritoriji Vojnog zapovednika za Srbiju. U članku se analizira na koji način i u kojoj meri su se građani okupiranog Beograda borili kako bi očuvali ove fundamentalne vrednosti jednog društva. Ovaj fenomen posmatran je i iz perspektive represivnog sistema. Ukazano je na metode rada policijskih i bezbednosnih struktura, kao i nivo represije prilikom obrade ove vrste prekršaja. Rad je nastao na osnovu arhivskog istraživanja, dopunjenog relevantnom literaturom $i$ periodikom.

KLJUČNE REČI: Drugi svetski rat, Beograd, propaganda, cenzura, verbalni delikt, Radio London, represija, civilni otpor

\section{Uvod}

Vojska koja je 12. aprila 1941. umarširala u Beograd predstavljala je državu čiji je politički vrh na dno ,rasne lestvice“ projektovao srpski narod, koji zbog svoje izmešanosti nije pogodan za asimilaciju i kome je u novom svetskom poretku bilo namenjeno mesto robovske radne snage. Ovakvi parametri zajedno sa činjenicom da je primaran cilj nacističke Nemačke bio pohod na istok rezultirali su nastojanjima da se zavođenjem strogog okupacionog režima i upotrebom što manjih vojnih efektiva ispune dva osnovna cilja okupacione uprave na teritoriji Vojnog zapovednika za Srbiju - pacifikacija i privredna eksploatacija. ${ }^{1}$

\footnotetext{
${ }^{1}$ Više o nacističkim projekcijama stanovništva srpske nacionalnosti i okupacionom sistemu na teritoriji Vojnog zapovednika za Srbiju: Ferdo Čulinović, Okupatorska podjela Jugoslavije (Beograd: Vojnoizdavački zavod, 1970); Milan Ristović, Nemački novi poredak i Jugoistočna Evropa: 1940/41-1944/45: planovi o budućnosti i praksa (Beograd: Vojnoizdavački i novinski centar, 1991); Muharem Kreso, Njemačka okupaciona uprava u Beogradu 1941-1944 (Beo-
} 
Zbog svoje višestruke važnosti kao političkog, privrednog i saobraćajnog centra očuvanje reda i mira u Beogradu bilo je od primarnog značaja za okupatora, što je zahtevalo uspostavljanje adekvatnog represivnog aparata. Kao i u samoj Nemačkoj i drugim gradovima okupirane Evrope, nosioci represivnog sistema na teritoriji Srbije bili su službenici tajne državne policije Gestapoa. Ovaj deo okupacionog represivnog aparata delovao je unutar Operativne grupe policije, a od januara 1942. Zapovednika policije bezbednosti i Službe bezbednosti. Beogradski Gestapo je imao devet referata formiranih prema delokrugu rada. Krivice po verbalnom deliktu i slušanju zabranjenih radio-stanica, prema svemu sudeći, nisu bile u delokrugu posebnog referata. U zavisnosti od toga da li su osumnjičeni iznosili prokomunističke ili proravnogorske stavove, ove predmete preuzimali su referati IV A1 (suzbijanje komunizma i levičarskih pokreta, borba protiv komunističkog pokreta otpora) odnosno IV A3 (praćenje i suzbijanje delatnosti Jugoslovenske vojske u otadžbini). Postojao je i poseban referat IV C1, čiji je delokrug rada obuhvatao operativnu obradu političkih protivnika koji su delovali samostalno u odnosu na pokrete otpora i zabranjene političke organizacije i udruženja.

Odeljenje specijalne policije Uprave grada Beograda, formirano na temeljima predratne Opšte policije, bilo je deo kolaboracionističke uprave koji je imao u delokrugu rada navedene prekršaje. „Lov“ na ljude koji agituju protiv okupacionog režima, slušaju zabranjene radio-stanice i čine slične prekršaje pripadao je delokrugu rada službenika IV antikomunističkog i III antiravnogorskog odseka. ${ }^{2}$ Pored navedenih represivnih struktura Beograd, kao centar okupacione uprave, bio je mesto sa najvećom koncentracijom ljudi u uniformama.

Navedene policijske i obaveštajne strukture imale su kao osnovni cilj otkrivanje i hapšenje svih neprijatelja Trećeg rajha i održavanje reda i mira na teritoriji Uprave grada Beograda. Službenici Gestapoa i Specijalne policije koristili su najrazličitije metode, kako bi uz pomoć sopstvenog osoblja i poverenika vršili kontrolu svih slojeva društva. Posle operativne obrade i hapšenja uhapšenici su podvrgavani saslušanju, prilikom kojeg je u slučajevima nekooperativnosti dolazilo do upotrebe fizičke sile. Pooštreno saslušanje, kako su službenici Gestapoa nazivali ovaj metod, označavalo je da su islednici „svoje žrtve prebijali volovskom žilom, pendrecima, električnom strujom“ i drugim sredstvima. Nakon istrage sastavljani su završni izveštaji i obrazovan personalni dosije. Sudbina uhapšenog u većini je zavisila od težine krivice. Najveći broj upućivan je u logor na Banjici, gde su bili deo rezervoara za podmirivanje kvota za streljanje ili su transportovani $u$ druge koncentracione logore i logore smrti na teri-

grad: Istorijski arhiv Beograda, 1979); Dragan Aleksić, „Površina i broj stanovnika na području vojnoupravnog komandanta Srbije“, Tokovi istorije, br. 4, (1999), 144-150.

${ }^{2}$ Više o organizacionoj strukturi i delokrugu rada Gestapoa i Odeljenja specijalne policije u: Nemačka obaveštajna služba (dalje: NOS) (Beograd: Državni sekretarijat za unutrašnje poslove, 1959), IV, 393-502; Бранислав Божовић, Спеиијална полииија у Београду 1941-1944 (Београд: Просвета, 2003); Bojan Dimitrijević, „General SS i policije August Majsner i srpski sistem bezbednosti 19421943“, Istorija 20. veka, br. 3, (2010), 69-83; Milan Koljanin, „Struktura i delovanje policije nacističke Nemačke u okupiranoj Srbiji 1941-1944“, Istorija 20. veka, br. 3, (2011), 143-156. 
toriji okupirane Evrope. Oni sa blažim krivicama puštani su na slobodu posle određenog vremena provedenog u logoru. ${ }^{3}$

Okupator je od prvog dana stavio do znanja građanstvu da će svaku vrstu neposlušnosti surovo kažnjavati. Izbijanjem ustanka u leto 1941. i pojavom prvih oružanih akcija represivni sistem je prešao sa reči na dela. Masovno je sprovođeno načelo kolektivne odgovornosti, koje je podrazumevalo streljanje uhapšenih pripadnika pokreta otpora i Jevreja kao mere odmazde i uzimanje talaca. Policijske i bezbednosne strukture usmerile su svoje kapacitete na otkrivanje i suzbijanje delatnosti komunističkog i ravnogorskog pokreta otpora. Gotovo svakodnevno su hapšeni pripadnici tih pokreta otpora, koji su nakon isleđenja u zavisnosti od ,krivice“" streljani ili upućivani u logore. Posebno je važno ukazati da je posedovanje ilegalnog štampanog materijala koji potiče iz štamparskih presa komunista ili ravnogoraca karakterisano kao ozbiljan prestup za koji je izricana i smrtna kazna. ${ }^{4}$

Na teritoriji okupirane Srbije okupator je preko svog Propagandnog odeljenja za jugoistok, to jest referata za film, štampu, pozorište i literaturu, kontrolisao i usmeravao rad svih sredstava javnog informisanja na teritoriji okupirane Srbije. U jesen 1941. osnovano je Odeljenje državne propagande pri Ministarskom savetu koje je imalo delokrug rada sličan predratnom Centralnom presbirou, ali je bilo u potpunosti potčinjeno okupacionim vlastima. Uvedena je stroga cenzura, naređeno je da se vlasnici sprava za umnožavanje pisanog materijala prijave okružnim komandama, a koliko se daleko išlo u težnji da se svi komunikacioni kanali stave pod nadzor, govori naredba prema kojoj su golubari bili u obavezi da pobiju svoje golubove pismonoše. ${ }^{5}$

$\mathrm{Na}$ ovaj način okupator je nastojao da zatvori protok informacija i pripremi teren za plasiranje propagande. Jedan od glavnih kanala preko koga su nacisti sa svojom propagandom mogli da dopru do stanovnika okupirane Srbije bila je štampa. Ukinut je rad međuratnih jugoslovenskih novinskih agencija i nisu obnovljeni dnevni i periodični listovi koji su izlazili u ovom periodu. Pokrenuti su novi dnevni i periodični listovi kao što su Novo vreme, Obnova i Srpski narod, čija su uredništva bila produžena ruka propagandnog odeljenja i koji su predstavljali nosioce propagandne matrice okupatora. ${ }^{6}$ Značajan kanal informisanja bio je

\footnotetext{
${ }^{3}$ Više u: Sima Begović, Logor Banjica 1941-1944, I, II (Beograd: Institut za savremenu istoriju, 1989); Logor Banjica: Logoraši, knjige zatočenika Koncentracionog logora Beograd-Banjica 1941-1944, I-II, pr. Evica Micković i drugi (Beograd: Istorijski arhiv Beograda, 2009); Milan Koljanin, Nemački logor na Beogradskom sajmištu 1941-1944 (Beograd: Institut za savremenu istoriju, 1992); Milan Koljanin, „Represija kao sistem - logori u okupiranoj Srbiji 1941-1945“, Hereticus, br. 1, (2007), 157-171.

${ }^{4}$ Više o otporu u Beogradu i represiji kao odgovoru na njega u: Раде Ристановић, „Облици отпора у окупираном Београду 1941-1944“ (докторска дисертација, Универзитет у Новом Саду, Филозофски факултет, Одељење за историју, 2019).

${ }^{5}$ M. Kreso, $n$. d., 74 .

${ }^{6}$ Više o ovoj temi u: Rade Ristanović, „Svakodnevica prvih meseci okupacije u člancima Beogradskih opštinskih novina“, Istorija 20. veka, br. 2, (2014), 95-110. Маријана Мраовић, „Пропаганда владе Милана Недића (1941-1944)“ (докторска дисертација, Универзитет у Београду, Филозофски факултет, Одељење за историју, 2015); Колаборачионистичка штампа у Србији 1941-1944, 1, ур. Александар Стојановић, (Београд: Филип Вишњић, 2015); Колаборачионистичка штампа y Србији 1941-1944, 2, ур. Александар Стојановић (Београд: Филип Вишњић, 2017).
} 
i Radio Beograd (Sender Belgrad), čime je okupator dobio još jedan kanal preko koga je imao mogućnost da vrši propagandu na većinu Beograđana, budući da je pred okupaciju oko 100.000 građana posedovalo radio-prijemnike. ${ }^{?}$

Propagandnu matricu koja je formulisana i korišćena na teritoriji okupirane Srbije karakterisali su opšti elementi poput antisemitizma, antiboljševizma, glorifikacije Trećeg rajha i nacističke ideologije, ali i posebni, kao što je kritika komunističkog i ravnogorskog pokreta otpora, jugoslovenske vlade u emigraciji, vodećih ljudi Srpske pravoslavne crkve itd. Autori koji su proučavali upotrebu propagande na teritoriji okupirane Srbije tokom Drugog svetskog rata saglasni su da je ona bila instrument u ispunjavanju osnovnih ciljeva režima - pacifikacije okupirane teritorije, privredne eksploatacije i ideološkog uticaja na stanovništvo. U ostvarenju ovog cilja žrtvovano je u većini načelo objektivnog informisanja i upotrebljavana je siva i crna propaganda. ${ }^{8}$

Okupator je u ranoj fazi svoje vladavine zabranio slušanje određenih radio-stanica. Naredbom Vojnog zapovednika za Srbiju od 27. maja 1941. stavljeno je izvan zakona ,slušanje pojedinih inostranih (ne nemačkih) radio stanica". Ova zabrana odnosila se na celokupan program. Beograđanima je bilo dozvoljeno da slušaju programe sledećih stanica: „Radio stanice protektorata Praga, Brna i Moravskih Ostrva“, „Velike radio stanice Dunav“, „Višnja“, „Luksemburg“, „Frizland“, „Varšava“, „Krakov“ i „Pariz“. ${ }^{9}$ Iz ovog popisa jasno uočavamo da je bilo dozvoljeno slušanje samo radio-stanica koje su bile pod potpunom kontrolom nacističke Nemačke. Oduzimanje aparata, kazna robijom, ,a u teškim slučajevima smrću“ bili su predviđeni za sve one koji su nameravali da slušaju radio-stanice van ovog spiska. ${ }^{10}$

Svi građani koji su posedovali radio-prijemnik, po naredbi kolaboracionističke uprave od 6. juna 1941, morali su da ih registruju u „Radio odeljku Glavnog telefona" i plate taksu od 10 dinara za prijavu i 75 dinara unapred za mesečnu pretplatu. ${ }^{11}$ Strogo su kontrolisane radnje koje su prodavale radioaparate i delove za ovu vrstu uređaja. Doneta je posebna uredba od 21. oktobra 1941. koja je predviđala da svi prodavci radio-aparata na području okupirane Srbije naprave popis celokupne robe, ovu dokumentaciju dostave nadležnoj

\footnotetext{
${ }^{7}$ Мирјана Николић, Sender Belgrad. Окупаиијски Радио Београд Зендер Белград: Радиофонија у Србији током Другог светског рата (Београд: Радио Београд, 2009), 11-15.

8 Široka upotreba propagandnih modela tokom Drugog svetskog rata razvila je formalnu definiciju bele, sive i crne propagande. Belom propagandom označavamo onu koja ima transparentne izvore i ciljeve. Siva je u pogledu informacija netransparentna, čime je njena relevantnost pod znakom pitanja. Prilikom upotrebe crne propagande informacije se serviraju kao da su potekle iz tabora onih koje diskredituju, a u stvarnosti su plod domaće propagandne kuhinje. Više o cenzuri i upotrebi propagande od strane nacističke Nemačke u: David Welch, The Third Reich: Politics and Propaganda (London: Routledge, 2007); Aristotel A. Kallis, Nazi Propaganda and the Second World War (New York: Palgrave Macmillan, 2005); Nicholas Stargardt, The German War: A Nation under Arms (London: Penguin Random House, 2015).

9 „Наредба о забрани слушања емисионих станица“, Лист уредаба војног заповедника у Србији, 31. 5. 1941, 84.

${ }^{10}$ Исто.

11 „Радио апарати се морају поново пријавити“, Ново време, 6. 6. 1941, 3.
} 
feldkomandanturi i da od iste zatraže odobrenje za dalju prodaju. ${ }^{12}$ Okupaciona obaveštajna služba služila se i lukavstvom, šireći glasine među građanstvom da poseduje tehnička sredstva uz pomoć kojih može da detektuje sve lokacije na kojima se slušaju zabranjene radio-stanice. ${ }^{13}$

Širenje zabranjenih vesti bilo je jednako kažnjivo kao i slušanje. Vojni zapovednik za Srbiju u jednoj od svojih prvih naredbi upozorio je građane da su kažnjive „naročito neprijateljske i uvredljive izjave“, kao i širenje radio i drugih vesti neprijateljskih prema Nemačkoj. ${ }^{14}$ Tačka 25 „Uredbe o primeni nemačkog kaznenog prava“ predviđala je: „Ko širi saopštenja ili vesti neprijateljske prema Nemačkoj, koje su podesne da škode ugledu Nemačkog Rajha ili nemačke vojne sile ili prouzrokuje nemire na okupiranom području ili čije je objavljivanje zabranjeno od strane okupacionih vlasti, kazniće se robijom, u lakšim slučajevima zatvorom. U naročito teškim slučajevima može se izreći smrtna kazna“. ${ }^{15}$ Zabranjeno je i izvođenje mnogih borbenih i patriotskih pesama u ugostiteljskim objektima i na drugim javnim mestima. I Uprava grada Beograda uputila je 24. juna 1941. obaveštenje da će se i verbalni delikt najstrože kažnjavati. Građani su upozoreni da ,će prema svima onim licima, koja nastoje širenjem neistinitih glasova da poremete red i mir, postupati sa svom strogošću“. ${ }^{16}$ Koliko je okupator pridavao veliki značaj suzbijanju slušanja zabranjenih stanica, svedoči izveštaj Centra za vezu Vermahta upućen 31. jula 1941. Komandi za Jugoistok. U njemu su uputstva koja su dolazila sa talasa Radio Londona i Radio Moskve označena kao glavni krivac za veći broj sabotaža u Beogradu. ${ }^{17}$ Prema jednom izveštaju koji je dobila emigrantska vlada, represivni organi vršili su noćne racije u vreme kada su emitovane vesti zabranjenih radio-stanica i na osnovu toplote radio-aparata ocenjivali su da je isti bio u funkciji. ${ }^{18}$

\section{Slušanje zabranjenih radio-stanica}

Ni antifašističkoj koaliciji nije promakao značaj propagandnog delovanja na okupiranom delu Evrope. Sve do stupanja savezničkih jedinica na teritoriju Francuske, akcenat britanske propagande nije bio na ohrabrivanju otpora, već na održavanju morala. U ovom kontekstu razlikujemo pripremnu i operativnu propagandu. Prva je trebalo da održi moral i pripremi stanovništvo kako bi u pogodnom trenutku bilo spremno da izvede direktive o podizanju ustanka. Operativna propaganda sastojala se od direktnih ili indirektnih instrukcija koje su

\footnotetext{
12 „Уредба о дужности тражења овлашћења за трговину са радио апаратима и саставним деловима радио апарата“, „Лист уредаба Војног заповедника у Србији, 21. 10. 1941, 179.

${ }^{13}$ Miroljub Jevtović, Šta kaže Radio London (Beograd: A-Š delo, 1989), 179-180.

${ }^{14}$ Војни заповедник Србије, „Наредба о полицијској власти команданта места“, Општинске новине, 25. 4. 1941, 3.

15 „Уредба о примени немачког казненог права и за заштиту унутарњег мира и окупационе силе“, Лист уредаба Војног заповедника у Србији, 8. 7. 1943, 352.

${ }^{16}$ Muzej žrtava genocida (MŽG), Zbirka Branislava Božovića (ZBB), cd br. 6.

${ }^{17}$ Vojni arhiv (VA), Nemačka arhiva (NAV) N-T-312, 454/8039293-95.

${ }^{18}$ VA, Emigrantska vlada (EV), kutija (k.) 349, fascikla (f.) 39, dokument (d.) 1.
} 
bile u službi širih vojnih ciljeva poput usporavanja rada u industrijskim postrojenjima, manjih sabotaža $\mathrm{i}$ tome slično. Kako bi postigli navedene zadatke britanski propagandisti koristili su tri vrste propagande: belu, sivu i crnu. ${ }^{19}$

Ključni medij, i tokom Drugog svetskog rata najpopularniji, uz pomoć kojeg je slobodni deo komunicirao sa okupiranim delom Evrope bio je Radio London. Sa frekvencije ovog radija Francuzima, Norvežanima, Dancima, Grcima i drugim narodima obraćali su se spikeri na njihovom jeziku i prenosili informacije o stanju na frontovima, pružanju otpora, itd. ${ }^{20}$ Prema određenim podacima, do 1944. oko $70 \%$ ljudi u Zapadnoj Evropi koji su posedovali radio-aparat slušali su ilegalne radio-stanice. U ovom pogledu represivni organi imali su ujednačen tretman. Oni koji su otkriveni da se na ovaj način informišu procesuirani su, a kazne su u zavisnosti od informacija koje su sakupljali varirale od zatvorskih do smrtnih. ${ }^{21}$

Tokom 1939. Velika Britanija je pri „Britanskoj radiodifuznoj korporaciji“ osnovala Jugoslovensku sekciju koja će uz ,pisanu reč“ predstavljati mačonošu u propagandnom ratu na teritoriji Kraljevine Jugoslavije. Od ovog perioda do okupacije Beograđani su učestalo slušali Radio London i imali poverenja u informacije koje je prenosio. ${ }^{22}$ Pod okupacijom Jugoslavije britanski propagandisti su još sistematičnije pristupili kreiranju programa za jugoslovenske slušaoce. Angažovani su stručnjaci za Balkan i članovi vlade u emigraciji. Program koji je emitovao Radio London na srpskom jeziku sastojao se od informacija dobijenih od novinskih agencija, obaveštajne službe ali i cenzurisanih tekstova koje je dostavljala jugoslovenska vlada u emigraciji. ${ }^{23}$ Kako ukazuje istoričar Joanis Stefanidis, osnovna poruka koju je britanska propaganda pokušavala da pošalje stanovnicima okupirane Jugoslavije bila je da nisu sami i da nisu zaboravljeni. ${ }^{24}$

Način izveštavanja Radio Londona bio je u potpunosti usklađen sa spoljnom politikom Velike Britanije prema Kraljevini Jugoslaviji. Sve do novembra 1942. o Ravnogorskom pokretu otpora na ovim talasnim dužinama dominirale su vesti u superlativu. Od ovog perioda Radio London polako utišava proravnogorsku i pojačava propartizansku propagandu. Od početka 1944. britanska propaganda daje punu podršku Narodnooslobodilačkom pokretu, a jedinice generala Dragoljuba Mihailovića postaju neprimetne. Zločini u NDH su osuđivani, ali su britanski propagandisti instruisani da kada govore o njima ne upotrebljavaju reč „Hrvati“ već „ustaše“ ili „frankovci“. Vlada Milana Nedića

${ }^{19}$ Više o uobličavanju metoda i ciljeva britanske propagande tokom Drugog svetskog rata u: Ioannis Stefanidis, Substitute for Power: Wartime British Propaganda to the Balkans, 1939-44 (Farnham: Ashgate Publishing Limited, 2012), 1-35.

${ }^{20}$ Temeljnu studiju o upotrebi Radio Londona u vršenju propagande tokom Drugog svetskog rata u okupiranoj Evropi napisao je istoričar Majkl Stenton: Michael Stenton, Radio London and Resistance in Occupied Europe: British Political Warfare 1939-1943 (Oxford: Oxford University Press, 2000).

${ }^{21}$ Дејан Зец, „Свакодневни живот у окупираном Београду (1941-1944)“ (докторска дисертација, Универзитет у Београду, Филозофски факултет, Одељење за историју, 2019), 235.

${ }^{22}$ Исто, 230.

${ }^{23}$ M. Jevtović, $n$. d., 123-126; Милан Терзић, „Делатност радио станице „Карађорђе“ у Јерусалиму“, Зборник Матиие српске за историју, бр. 88, (2013), 57-71.

${ }^{24}$ I. Stefanidis, op. cit., 236. 
oštro je osuđivana i predstavljana kao deo nemačkog plana čija je suština ,zavadi pa vladaj“،. Eksploatisano je prorusko raspoloženje, veličana borba Crvene armije i savezničke koalicije, izveštavano o delatnosti vlade u emigraciji itd. ${ }^{25}$ Čitajući pojedine vesti zaključujemo da ni britanski propagandisti nisu oklevali da koriste sivu i crnu propagandu kako bi postigli svoje ciljeve. ${ }^{26}$

Od prvog meseca okupacije u Beogradu je slušan i Radio Moskva ali, usled udaljenosti i presečenih komunikacija, program ovog radija nije pružao veliki broj informacija o dešavanjima u okupiranoj Kraljevini Jugoslaviji. U novembru 1941. pod okriljem Kominterne u gradu Ufa osnovana je radiostanica Slobodna Jugoslavija koja je postala glavni izvor informacija Beograđana o delovanju komunističkog pokreta otpora. ${ }^{27}$ Slušajući ovaj radio građani su mogli, ako su imali mapu Jugoslavije, da prate i ucrtavaju vojne operacije koje je na teritoriji Kraljevine Jugoslavije izvodio NOVJ, da se upoznaju sa političkim delovanjem ovog pokreta otpora i slušaju kritiku JVuO, okupatora i kolaboracionista. Analiza načina na koji su interpretirane navedene vesti ukazuje na to da je Radio Slobodna Jugoslavija bio pristrastan, da je koristio crnu propagandu u cilju veličanja NOP-a i diskreditacije suparničkog pokreta otpora. ${ }^{28}$

Vesti koje su emitovale zabranjene radio-stanice slušane su u najvećoj tajnosti pod okriljem mraka, samostalno ili u društvu ljudi koji su uživali bezgranično poverenje domaćina. Ovako prikupljene informacije prenošene su usmeno, a bilo je i onih smelijih koji su ih zapisivali kako bi raspolagali što tačnijim informacijama. ${ }^{29}$ Prema podacima američkog diplomatskog predstavništva u Beogradu, građani prestonice su već u avgustu 1941. masovno slušali zabranjene radio-stanice. ${ }^{30}$ Obaveštajni izveštaji koje je dobijala vlada u emigraciji takođe navode da Beograđani slušaju zabranjene radio-stanice, prenose vesti, ali i da je sve to kažnjivo. Više o popularnosti i percepciji vesti Radio Londona među Beograđanima saznajemo iz dela izveštaja koji je marta 1942. Poslanstvo u Stokholmu poslalo vladi u Londonu: ,Radio London se čuje vrlo dobro u Beogradu. Mnogi ga slušaju, mada se slušanje kažnjava smrću. Vesti se šire prepričavanjem. U tom učestvuju i mnogi viši policijski činovnici. Emisije na našem jeziku nailaze na jako dobar prijem, naročito govori i predavanja koja se odnose na savezničke napore da se dobije pobeda i oslobode okupirane zemlje, jednom rečju sve što jača moral i nadu na skoro oslobođenje“ ${ }^{31}$

Grupe za slušanje Radio Londona i Radio Moskve okupljane su na najrazličitije načine. Poznanstvo ostvareno prilikom klanja svinja u septembru 1941. između Spasoja Jakovljevića šofera, Stojana Medića mesara i Nedeljka Korice

\footnotetext{
${ }^{25}$ Isto, 238-264.

${ }^{26}$ M. Jevtović, $n . d ., 163,233$.

${ }^{27}$ Više o ovoj temi u: Veljko Vlahović, Borba za slobodnu Jugoslaviju (Beograd-Titograd: Komunist-Pobjeda, 1981).

${ }^{28}$ Arhiv Jugoslavije (AJ), Uprava grada Beograda Specijalna policija (UGB, SP), k. 2-238.

29 Д. Зец, н. д., 233-234.

${ }^{30}$ Nacional Archives of Washington (NAW), fond: Department of State (f. DS), Consular reports on Yugoslavia (CRY) 750/40.

${ }^{31}$ AJ, fond 382, Poslanstvo Kraljevine Jugoslavije u Švedskoj - Stokholmu, k. 1.
} 
konobara preraslo je u kružok za slušanje zabranjenih radio-stanica. Radio i smeštaj u Kostolačkoj ulici pružao je Jakovljević, a sastanci su održavani i nakon policijskog časa. Informacije prikupljene na ovaj način Jakovljević je distribuirao svojim prijateljima i poznanicima. U oktobru 1941. ova grupa je otkrivena uz pomoć dostave Milorada Vasiljevića koji je prijavio da Medić napušta stan posle policijskog časa kako bi slušao zabranjene vesti. ${ }^{32}$ Uz pomoć Medića Gestapo je došao do Jakovljevića i Korice, koji su na saslušanju priznali počinjeno „delo“. Nakon okončanja istrage islednici su zaključili da su Jakovljević i Medić distribucijom informacija ,proigrali svoj život“" $\mathrm{i}$ da ih treba pogubiti. ${ }^{33}$ Pred streljački vod Jakovljević i Medić izvedeni su 3. novembra 1941. ${ }^{34}$ Treći član grupe Korica odveden je u logor na Banjici gde je izdržao kaznu od 19 meseci. Pušten je 26. jula 1943, uz pristanak da radi za nemačku policiju. ${ }^{35}$

Francuz Julijus Bertoa pored svog ,dnevnog posla“ (šofer u organizaciji Tot) bio je i poverenik Gestapoa koji je, kao jednu od dužnosti, imao da osluškuje šta se priča po javnim mestima i stupa u kontakt sa onima koji govore protiv okupatora. U januaru 1943. njegovim delovanjem uhapšen je Dušan Dimić. ${ }^{36}$ Ovaj Beograđanin upoznao je Bertoa u kafani „Koštana“ i pozvao ga da slušaju zabranjene radio-stanice. Na ovaj način otkrivena je i uhapšena veća ,slušačka“ grupa u kojoj su, pored Dimića, bili i: Vojislav Ćirković, supružnici Sava i Slavka Dabić, Krsta Martinović, Gligorije Popović i Ivanka Radić. Na prvom saslušanju 14. januara Dimić je opovrgao sve optužbe i islednici su tražili da se podvrgne ,pooštrenom“ saslušanju. Posle torture priznao je da je od jula 1942. slušao zabranjene radio-stanice i zapisivao vesti, da je pozivajući Francuza da slušaju radio nastojao da mu dokaže da borbu vode komunisti, a ne JVuO i da je samoinicijativno proučavao komunističku ideologiju. Istraga je utvrdila da je radio-aparat svojeručno napravio Sava Dabić, nadstojnik zgrade u Kolarčevoj 3, koji je obezbeđivao i smeštaj za slušanje vesti, kao i da su svi uhapšeni povremeno dolazili na ,projekcije“ emisija Radio Londona i Radio Moskve.

Posle istrage Dimić je predložen za pogubljenje, Ćirković, Martinović i Sava Dabić da se odvedu na prinudni rad, a Slavka Dabić, Popović i Martinović da se sprovedu u logor na Banjicu. Na slobodu je puštena Ivanka Radić. Poseban kuriozitet predstavlja slučaj konobara Jovana Avramovića koji je pripadao ovoj grupi, ali nije ni uhapšen. Kao olakšavajuće okolnosti uzete su mu činjenice da je tokom Prvog svetskog rata ranjen prilikom službe u austrougarskoj vojsci i da je bio uslužan prema gostima nemačke nacionalnosti. Prema raspoloživim podacima Dušan Dimić je streljan 9. februara iste godine, Sava Dabić je preminuo u logoru Mauthauzen, a Martinović i Slavka Dabić pušteni su iz logora 7. aprila 1943. ${ }^{37}$

\footnotetext{
${ }^{32}$ Istorijski arhiv Beograda (IAB), Zapovednik službe policije bezbednosti i službe bezbednosti (BDS), registar (reg.) Mau-Mih.

${ }^{33}$ IAB, BDS, J-136, Spasoje Jakovljević.

${ }^{34}$ Logor Banjica, I, 122.

${ }^{35}$ Isto.

${ }^{36}$ IAB, BDS, reg. br. 5, Ben-Blu.

${ }^{37}$ IAB, BDS, D-704, Dušan Dimić; IAB, BDS, reg. br. 12, Da-De.
} 
Sledeća ,žrtva“ Francuza bio je arhitekta Milorad Jovanović. Tokom neformalnog razgovora u aprilu 1943. u jednoj od beogradskih berbernica upoznali su se Jovanović i Bertoa. Činjenica da je Bertoa bio stranac u Beogradu i da je Jovanović znao francuski produbila je poznanstvo. Prilikom daljeg viđanja Jovanović je pokušao da utiče na novostečenog prijatelja govoreći mu da će ljudi koji rade za Nemce biti likvidirani, da je u posedu stanovništva velika količina naoružanja. Ono što ovaj Beograđanin nije znao o novom francuskom prijatelju jeste da radi za nemačku obaveštajnu službu. Gestapo je izdao nalog za hapšenje Milorada Jovanovića 19. aprila i posle pretresa njegovog stana policijski službenici su pronašli radio-aparat sakriven u dečijoj sobi. Na saslušanju Jovanović je priznao navode iz optužnice, što je opredelilo islednika da predloži njegovu egzekuciju. ${ }^{38}$

Ni pripadnici beloemigracije nisu bili imuni na vesti iz domovine. U stanu Nikole Šugajevskog u Krunskoj ulici 22 slušali su Radio Moskvu imenovani, Nikolaj Lobanov vojnik u nemačkoj vojsci, Andrej Jasin i supružnici Aleksandar i Stana Ivanov. Grupa je diskutovala i o položaju Rusa u okupacionim jedinicama. Nemačka policija je saznala za grupu i uhapsila njene pripadnike 9. aprila 1943. Izuzev Šugajevskog, svi su priznali pred islednicima svoju „krivicu““ ${ }^{39}$ Nakon istrage i određenog vremena provedenog u logoru na Banjici pred streljački vod 7. maja izvedeni su Ivanov i Šugajevski, a Ivanova je 7. jula 1943. odvedena u Aušvic. ${ }^{40}$

Ličnom neopreznošću u maju 1943. Ivan Damjanović doveo je sebe i svoju suprugu u nezavidan položaj. Konstatovao je pred poverenikom Gestapoa pod šifrom D-34 da tadašnja situacija zahteva da čovek ima na raspolaganju dobar radio-aparat kako bi mogao da sluša zabranjene radio-stanice. Poverenik Gestapoa je zaključio da je Damjanović simpatizer „neprijateljskih sila“ i da vodi „neprijateljsku“ propagandu. Pokrenuta je istraga 18. juna i uhapšena je Damjanovićeva supruga, jer je on bio na putu. Na saslušanju islednici Gestapoa dobili su priznanje da su supružnici slušali zabranjene radio-stanice. Sutradan je uhapšen i Damjanović, ali je pred islednicima opovrgao optužbe i izjavio da radio-aparat koji poseduje nije u funkciji. Gestapo je proverio navode i nakon testiranja utvrdio da je aparat ispravan.

U završnom izveštaju odgovorni referent je predložio da se Damjanović uputi na prinudni rad, a njegova supruga pusti na slobodu. ${ }^{41} \mathrm{O}$ tome koliko skupo je ovaj čovek platio svoju neopreznost, ali i kakvog karaktera je bio represivni sistem okupatora svedoče sledeći redovi iz Knjige banjičkih logoraša: „Damjanović Ivan, trgovac, rođ. 19. III 1909. u Pakracu; od Stanka i Bojane Kožlović. U logoru od 24. VII 1943 - SS. Streljan 30. VII 1943. od SS“. ${ }^{22}$ Posle napada na rudnik „Bogovina“ Nemci su raspisali kvotu za odmazdu, a jedno od imena ,na spisku“ - uprkos prvobitnoj odluci o slanju na prinudni rad - bilo je i Damjanovićevo. ${ }^{43}$

\footnotetext{
${ }^{38}$ IAB, BDS, J-790, Milorad Jovanović.

${ }^{39}$ IAB, BDS, reg. br. 25, Im-Iz.

${ }^{40}$ Logor Banjica, II, 70.

${ }^{41}$ IAB, BDS, D-889, Ivan Damjanović.

${ }^{42}$ Logor Banjica, II, 231.

${ }^{43}$ IAB, BDS, D-889, Ivan Damjanović.
} 
Stanodavac Muhamed Hadžić otkazao je sobu Radmili Kastratović i Miri Bogićević, jer su prema njegovoj proceni širile nemoral i sumnjao je da su ga opljačkale. Stanarke su prijavile okupacionim vlastima da Hadžić sluša zabranjene radio-stanice i da im preti kako će biti obešene na Terazijama zbog druženja sa jednim nemačkim oficirom. Ovaj rođeni Konjičanin uhapšen je i saslušan 25. maja 1943. od strane Gestapoa. Uprkos činjenici što je sve opovrgao, istraga je utvrdila da je slušao zabranjene radio-stanice. Kao olakšavajuća okolnost uzeta je činjenica da je prijava podneta iz „mržnje“, što je opredelilo nadležnog referenta da predloži kao kaznu oduzimanje radio-aparata i opomenu. Po puštanju na slobodu Hadžiću je skrenuta pažnja da u slučaju ponovljenog prekršaja može da očekuje „smeštaj u logoru“, a on se obavezao da će prijaviti sve koji budu govorili protiv Nemačke i njenih trupa. ${ }^{44}$

I nesređeni porodični odnosi u pojedinim slučajevima prouzrokovali su da se su ljudi iz istog ,doma“ prijavljivali policiji između sebe. Jedan od primera je Radmila Šarčević, koja je pismenim putem 1. decembra 1943. prijavila Gestapou svog oca Vladimira i maćehu Jelenu Antić da slušaju zabranjene radio-stanice i da su komunisti. Supružnici su uhapšeni 23. januara 1944. Prilikom saslušanja Jelena je porekla, a Vladimir priznao „delo“, ali je nakon suočenja i Antićeva priznala da su zajedno slušali Radio London. Posle istrage Vladimir je upućen u Mauthauzen na prisilan rad, a Jelena je puštena 11. aprila $1944 .{ }^{45}$

\section{Protivokupatorska retorika}

Izražavanje nezadovoljstva vladajućim režimom predstavlja pojavu koja je verovatno stara koliko i organizovano upravljanje društvenim zajednicama. Koliko će glasan biti glas „opozicije“ zavisi od razmera socijalnih razlika, narušavanja osnovnih sloboda i vrednosti pojedinca i drugih faktora. Ovaj fenomen koji se manifestuje i spontano kroz svakodnevni razgovor, pevanje i pisanje pesama, šaljivih priča i druge oblike ima najviše šansi da „proklija“ u uslovima okupacije. Iskustva u okupiranim evropskim zemljama tokom Drugog svetskog rata potvrđuje ovu tezu. U Norveškoj su, kako zaključuje Katlin Stoker, antiokupatorske šale bile veoma raširena pojava koja je uticala na promenu svesti i mišljenja, posebno u početnom periodu okupacije kada oružani otpor gotovo nije postojao. Antiokupatorska retorika je bila jedan od retkih oblika otpora nakon sloma pokreta otpora u okupiranom Pragu. U Strazburu su pojedini građani u znak protesta, uprkos zabrani, na ulici govorili francuski jezik. Kao i slučaju slušanja zabranjenih radio-stanica, okupator je ovaj prekršaj strogo kažnjavao. ${ }^{46}$

\footnotetext{
${ }^{44}$ IAB, BDS, D-251, Muhamed Hadžić.

${ }^{45} \mathrm{IAB}, \mathrm{BDS}$, reg. br. 2, AM-AN.

${ }^{46}$ Henri Michel, The Shadow War: European Resistance 1939-1945 (New York: Harper \& Row, 1972), 76-80; Cathleen Stokker, Folklore Fights the Nazis: Humor in Occupied Norway 1940 1945 (Madison: The University of Wisconsin Press, 1997), 206; Chad Brayant, "The Language of Resistance Czech Jokes and Joke-telling under Nazi Occupation, 1943-1945”, Journal of Contemporary History, vol 41, (1), 133-151.
} 
Da se Beograđani neće izdvajati od drugih građana evropskih prestonica, represivni organi su mogli da uoče već u leto 1941. „Srpska mi truba zatrubi/ U tovo selo Drenovo/ Spremte se spremte četnici/ Silna će borba da bude“, stihovi su jedne od najpopularnijih četničkih pesama sa početka 20 . veka koju je okupator stavio na ,crnu listu“. Svi poštovaoci ove junačke pesme rizikovali su da budu uhapšeni ukoliko bi se usudili da traže njeno izvođenje ili ako bi je sami pevali. Ovom riziku izložila su se dvojica nepoznatih mladića u kafani „Mali Jataganac" 27. jula 1941. Izvođenje numere nije ostalo neopaženo, pa su u kafanu ubrzo ušli nemački vojnici i uhapsili sve prisutne. Istraga je utvrdila da su nepoznati počinioci pevali samostalno bez pratnje orkestra i da su nakon toga otišli u nepoznatom pravcu. ${ }^{47}$

Bilo je i pojedinaca koji su svoje nezadovoljstvo izražavali putem anonimnih pisama koje su upućivali nosiocima okupacionog režima. Na Terazijama su 17. avgusta 1941. obešena petorica pripadnika komunističkog pokreta otpora. Većina izveštaja savremenika koji su u posleratnom periodu ostavili pisani trag o ovom zločinu saglasni su da su stanovnici Beograda bili zgroženi tim činom. ${ }^{48}$ Skloni smo da poverujemo da osećanja većine Beograđana prema ovom zločinu na najbolji način izražava pismo anonimnog autora upućeno 25. septembra komandantu za Srbiju generalu Hajnrihu Dankelmanu: „Znam da kao Silni Zapovednik Srbije, vaša kultura nama svima je poznata jer nevine ljude na sred Terazija ste pod imenom komunisti i razbojnici vešali, a ako Bog da možemo i vas i pored sve vaše garde da u društvu sa pretsednikom vlade borbašem Ljotićem da vidimo kako isto na Terazijama visite“" 49

Pesme sa političkom konotacijom pisane u vulgarnom ili duhovitom stilu kružile su među Beograđanima u drugoj polovini 1941. U džepu majstora za mašinske aparate tekstilne industrije, Čeha Jana Buhevalda, Gestapo je pronašao pesmu sledeće sadržine: „Agencija D. N. B./ Javlja iz Berlina, / Hitler j..o Musolina, / A grof Cano Ribentropa,/ Pa se trese sva Evropa./ Kabaljeru pali brci,/ Jer ga j..u dobro Grci,/ Mečka ćuti kažu drema,/ niko ne zna šta kom sprema;/ U Sofiju Hitler stigo,/ I Filovu noge digo,/ U Beograd Hitler ne sme,/ pevaju mu gadne pesme/ Antonesku kurva stara,/ I Filova nagovara/ Pa mu piše sad u aktu/ Priđi brate trojnom paktu/ O Hitleru, Hitleru,/ J....o ti nanu/ Ako počneš vršljati/ ovde na Balkanu““. ${ }^{50}$ Nemačka policija nije htela da oprosti Buhevaldu ,krivicu“; mada je pesma nastala u predratnom periodu, njen sadržaj je vređao firera i njegove saveznike. Ovaj Čeh je predložen za transport u jedan od koncentracionih logora, ali ga je spasila činjenica što je bio jedan od retkih specijalista za mašine koje obrađuju vunu pa je pušten 23. septembra 1941. ${ }^{51}$

Ogorčen i ljut što ga je poslodavac Đoka Dimić, suvlasnik fabrike sode, ukoravao kada je na posao dolazio u alkoholisanom stanju, kočijaš Slobodan

\footnotetext{
${ }^{47}$ IAB, Uprava grada Beograda, Odeljenje specijalne policije (dalje: UGB SP, IV) - 314-D.

${ }^{48}$ VA, EV, k. 349c, f. 3, d. 2; VA, Nezavisna Država Hrvatska (dalje: NDH), k. 61, f. 12, d. 4.

${ }^{49}$ IAB, UGB SP, IV, 157/15.

${ }^{50} \mathrm{IAB}, \mathrm{BDS}, \mathrm{B}-157$, Jan Buhevald.

${ }^{51}$ Isto.
} 
Ostojić podneo je prijavu nemačkoj policiji. Optužio je Dimića da sluša neprijateljske radio-stanice $\mathrm{i}$ da je davao informacije radnicima ove fabrike da su Rusi probili nemački front, da Nemci nisu više kod Lenjingrada itd. Pokrenuta je istraga 12. oktobra 1941. i uhapšen je Dimić, a kao svedoci pozvani su radnici Lazar Drvenica i Milenko Šiljak. Na saslušanju Dimić je nastojao da opovrgne optužbe i da celokupnu situaciju prikaže kao osvetu nezadovoljnog radnika. Otežavajuća okolnost bila mu je što je Šiljak potvrdio navode Ostojića. Ovo je bilo dovoljno da islednici „osude“ ovog 21-godišnjeg sodadžiju na četiri meseca logora. ${ }^{52}$ Dimić je sproveden na Banjicu 28. oktobra 1941, gde je ostao do 12. februara 1942. ${ }^{53}$ Posleratna služba bezbednosti zainteresovala se u novembru 1953. za ovaj slučaj i sprovela istragu. Dimić je u saslušanju priznao da je slušao zabranjene radio-stanice, opisao torturu kojoj je bio izložen i kao ključni razlog za puštanje iz logora naveo mito u iznosu od 400.000 dinara. $^{54}$

Uobičajene razgovore o političkim temama na krsnim slavama praktikovali su i Beograđani tokom okupacije. Dom Ljubice Pešić u Kosovskoj 51 u vreme Aranđelovdana 1941. bio je poprište na kome je diskutovano o delovanju komunističkog pokreta otpora. Na konstataciju jednog od gostiju koji je radio u kolaboracionističkoj upravi da sve partizane treba streljati reagovao je inženjer agronomije Momčilo Savićević i uputio salvu uvreda na račun vlade Milana Nedića, upravnika grada Dragog Jovanovića, te zapretio da će svi oni „visiti na Terazijama“. Izneo je niz pohvala partizanskom pokretu: da je ,„pobeda partizana gotova stvar“, „da će kroz koji mesec zauzeti Beograd“, da „,ih vode pošteni ljudi i intelektualci“، itd. Razgovor je došao do službenika Specijalne policije koji su prvo saslušali svedoke i nakon sakupljanja dokaza 12. decembra uhapsili Savićevića. On je na saslušanju delimično priznao da je govorio u prilog KPJ, ali je naglasio da nije deo njihove organizacije i da je bio motivisan nacionalnim pobudama. ${ }^{55}$ Posle istrage upućen je u logor na Banjici, gde je ostao do 1. aprila 1942. kada je pušten na slobodu. ${ }^{56}$

U novembru 1941. nemačka policija dobila je informaciju od svog poverenika da je Mila Aleksijević, bivša sekretarica u poslanstvu Velike Britanije u Beogradu, slušala zabranjene radio-stanice i govorila protiv okupacione sile. $\mathrm{Na}$,teret optužnice“ joj je stavljeno da je tvrdila da je „Nemačka predložila Rusiji mir ali da je to odbijeno“, „da će Amerika izvršiti avionima invaziju na Italiju“ itd. Ove navode potvrdili su svedoci Tadej Strbulović i Natalija Dželatović, ali je Aleksijevićeva na saslušanju od 31. novembra sve opovrgla. Za praksu Gestapoa izneti dokazi bili bi dovoljni za sprovođenje u logor, ali je ova Beograđanka puštena na slobodu 10. januara 1942. posle intervencije Dragog Jovanovića, predsednika Opštine grada Beograda, koji je bio njen nadređeni. ${ }^{57}$

\footnotetext{
${ }^{52}$ IAB, BDS, D-137, Đorđe Dimić.

${ }^{53}$ Logor Banjica, I, 124.

${ }^{54} \mathrm{IAB}, \mathrm{BDS}, \mathrm{D}-137$, Đorđe Dimić.

${ }^{55}$ IAB, UGB, SP, IV-Q- 9/11.

${ }^{56}$ Logor Banjica, I, 279.

${ }^{57}$ IAB, BDS, A-142, Mila Aleksijević.
} 
Okupaciona uprava je nastojala da zainteresuje što veći broj ljudi za odlazak na rad u Treći rajh. Propagandna sredstva su izveštavala o životnim i radnim uslovima onih koji su već otišli u superlativima, kako bi se što veći broj stanovnika privoleo na ovaj korak. Radnik na odsustvu Petar Golubović, obilazeći beogradske kafane, pružao je svojim sugrađanima drugačiju perspektivu. U ugostiteljskom objektu Dobrosava Krvljanca u ulici Đakona Avakuma 45 pred ovim gostioničarem i gostima Magdalenom Beker i Ivanom Onicinim podelio je 29. januara 1942. svoje impresije i negativna iskustva o radu u Nemačkoj. Kako je tom prilikom psovao nemačku državu i Adolfa Hitlera, prijavljen je od strane prisutnih i uhapšen od Gestapoa. ${ }^{58}$ Kakva kazna je čekala one koji su se u okupiranoj Srbiji „,drznuli“ da izvrgavaju ruglu prvog čoveka Trećeg rajha i prenose negativna iskustva o radu u ovoj zemlji saznajemo iz sledećih redova iz Knjige banjičkih logoraša: „Golubović Petar, fabrički radnik; rođ 12. III 1912. u Beogradu; od Sofije i Luke; oženjen, 3 dece; Beograd. U logoru od 18. II 1942Gestapo. Streljan 5. III 1942. u Beogradu“. 59

Srpska epska narodna pesma bila je deo školskog programa, ali i poezija sa kojom su se stanovnici ovog dela Kraljevine Jugoslavije susretali od malih nogu. Stihove u desetercu znali su napamet svi uzrasti, a njihova sadržina često je poistovećivana sa istorijskom istinom. Stražar Živorad Milanović bio je, prema svemu sudeći, poštovalac narodne književnosti i jedan od ljudi koji su, oslanjajući se na njen stil i estetiku, opisivali tadašnje događaje. Njegova pesma „Rat Srba i Nemaca" prvorazredno je svedočanstvo o nivou informisanosti običnog stanovništva, njihovom viđenju brzog sloma tokom Aprilskog rata, nadanjima da će „Rusi i Amerikanci“ poraziti Nemačku i svesti o strahovitim zločinima nad Srbima u NDH.

$\mathrm{Na}$ ovom mestu citiramo deo pesme o događajima koji su se odigrali pod okupacijom: „Al da vidiš rođaka Staljina/ Tvorcu vere on zadade svima/ Odmah sede na zlatnu stolicu/Uze pero u ruku desnicu/ Stade pisat slova i rječji/ Živo srce u grudi mu ječi/ Hitlera će u Berlinu da zgnječi/ U kratko mu sitnu knjigu piše/ Neće Hitler napredovat više/ U knjizi mu ovako govori/ Ruska vojska silu će ti slomi/ O Aždajo što gutaš Slovene/ Ako smješ udari na mene/ Da junački megdan podelimo/ Ako meni na megdan ne smiješ/ Ti mi predaj ključe od Berlina/ I Geringa tvoga nesretnog sina/ Sad da vidim rođaka Staljina/ Slovenima naređuje svima/ Svi ustanite na noge lagane/ Ubijajte te proklete Germane/ Da njihovo uništimo seme/ Bog da živi svu braću Slovene/ A za Srbe svoj bi život dao/ Jer su Srbi naša braća prava/ Sad ih neće zaboleti glava/ Mili Bože na svemu ti hvala/ Sad Nemačka na Ruse napala/ Rusi su im popustili malo/ Hitleru se to jako dopalo/ Misli Hitler da će uvek tako/ Da će Gering napredovat lako/ Al se braća vrati naopako/ Rusi vojska odupre se jako/ A Nemačka povlači polako/ Ruska vojska potuče ih silno/ Dođe Hitler pa smeni Geringa/ I od njega preduzme komandu/ Još povede zlikovačku bandu/ Da mu vojsku stave pod komandu/ I to njemu pomoći nemože/ Šta ću sada o jedini Bože/ Rusima se na put stat ne može/ Mili Bože šta da radim sada/ Na sve strane Nemačka

\footnotetext{
${ }^{58}$ IAB, BDS, reg. br. 20, Geb-Goz.

${ }^{59}$ Logor Banjica, I, 332.
} 
propada/ Sada slušajte moja braćo draga/ Šta uradi Pavelića vlada/ Naređuje Hrvatima svima/ Da Srbima ruše glave svima/ Pohvatali Srbe i Srpkinje/ Pohvatali i staro i mlado/ U Srpsku ih crkvu nateralo/ Pa uđoše po devet dželata/ Jadni Srbi kukala im majka/ Pred oči im nož naoštrili/ I krvnički u njih udarili/ Nekog nožom u srce udara/ Nekom braćo živu kožu para/ Mala Deca plaču i kukaju/ Mrtvoj majci za skut se hvataju/ Krv piju ni to žao nije“. 60

Pesnički dar ovog stražara nije ostao neopažen ni kod njegovih pretpostavljenih zahvaljujući kolegi stražaru Petru Radeki kod koga je pronađen izvod pesme prilikom pretresa u februaru 1942. Uhapšen je i Živorad Milanović, kod koga je pored pesme pronađena žalba adresirana na upravnika grada Dragog Jovanovića u kojoj se ukazuje na loš tretman oficira prema potčinjenim. Stražar je otpušten iz službe i predat Specijalnoj policiji. Na saslušanju 7. aprila Milanović je priznao da je autor tekstova koji su pronađeni kod njega i istakao da mu je stražarska dužnost teško padala i da nije komunista. Nakon isleđenja upućen je u logor na Banjici, jer je „shvatio svoj poziv olako“, pisao pesmu u kojoj je hvalio „Staljina i Rusiju“ i javno pokazivao neraspoloženje. ${ }^{61}{ }^{1}$ Zbog svog „pesničkog talenta" $u$ logoru je proveo više od godinu (pušten je 30. jula 1943). ${ }^{62}$

Pored primarne i zvanične funkcije da vrše snabdevanje Beograđana, pijace su bila mesta na kojima su građani mogli da se informišu ili dezinformišu. Za razliku od skromne ponude namirnica tokom okupacije, pijačni prodavci raspolagali su velikim brojem nezvaničnih informacija koje su bili spremni da podele sa kupcima. Jedan od navedenih bio je vlasnik tezge na Bajlonijevoj pijaci Žarko Jakovljević. On je svojim kupcima, pored voća i povrća, nudio priče u kojima je isticao: „da će doći dan kada će nemačke trupe napustiti Srbiju i da će onda sve Švabe-folksdojčeri biti ubijeni [...] da će doći vreme kada ćemo mi za svakog Srbina streljati 10 Nemaca [...] da u toku srpske osvete nećemo prezati ni od toga da ubijamo nemačku decu u kolevkama“.63

Svoje zapaljive govore Jakovljević je posebno držao pred ljudima za koje je imao informacije da su pronemački orijentisani i da nisu srpske nacionalnosti. U kojoj meri je branio svoje stavove svedoči činjenica da je Anu Markin fizički napao i povredio joj glavu oštrim predmetom. Od te Beograđanke je stigla prijava Gestapoa u februaru 1942. Jakovljević je optužen da je održavao kontakte sa komunističkim pokretom otpora i da je antinemačkog opredeljenja. Te navode podržali su Anin suprug Petar i ćerka Mirjana. Na saslušanju od 23. februara Jakovljević je opovrgao optužbe, ali je prema svemu sudeći zbog „pooštrenog saslušanja“ dva dana kasnije priznao sve. Istragom je utvrđeno da je ovaj piljar dobijao informacije slušanjem Radio Londona i Radio Moskve od Miše Majića i Alojza Sunarca u kafani „Banja Luka“. Uprkos činjenici što su imenovani prikupljali vesti slušanjem Radio Londona i Radio Mosvke i dalje ih prenosili trećim licima, policija nije proširila istragu i izvršila dalja hapšenja.

\footnotetext{
${ }^{60} \mathrm{IAB}, \mathrm{UGB}, \mathrm{SP}, \mathrm{IV}-64 / 9$.

${ }^{61}$ Isto.

${ }^{62}$ Logor Banjica, I, 370.

${ }^{63}$ IAB, BDS, J-251, Žarko Jakovljević.
} 
U završnom izveštaju povodom ove istrage nadležni referent zaključio je: „Jakovljević ostavlja nepovoljan utisak u karakternom pogledu se može označiti kao loš. Njegova nagovaranja na zločin ne predstavljaju samo prazne fraze, već se može i bez daljeg smatrati da bi ih i sproveo u delo. Prema nemačkom pravnom osećaju je Jakovljević usled navedenih dela i s obzirom na sadašnju političku situaciju u Srbiji proigrao svoj život. Predlažem ga stoga na pogubljenje." ${ }^{64}$ Islednik je na ovaj način neposredno ostavio upečatljivo svedočenje represivne politike nacističke Nemačke u okupiranoj Srbiji, koja je svaki pokušaj otpora surovo kažnjavala. Predlog islednika prihvatio je šef beogradske ispostave Gestapoa Bruno Zatler. Ime Žarka Jakovljevića ubačeno je u spisak za streljanje, 10. marta 1942. upućen je u logor na Banjici, a egzekucija je izvršena 9. maja 1942. ${ }^{65}$

Bez obzira na cenzuru, vesti o zločinima u Nezavisnoj Državi Hrvatskoj dopirale su do Beograđana. Glavni izvor informisanja bile su izbeglice koje su dolazile sa ovog prostora. Poslanstvo NDH u Dobračinoj ulici u Beogradu osluškivalo je ,puls“ stanovništva u Srbiji i prosleđivalo u Zagreb podatke o izlivima antiustaškog raspoloženja. Glavni konzul dr Ante Nikšić je u izveštaju „,O prilikama u Srbiji“، od 18. maja 1942. zapisao sledeću pesmu koju prema njegovim rečima pevaju „Srbi-izbjeglice“ i Beograđani „kada se ponapiju na svim svojim sastancima i terevenkama“ u Beogradu: „Paveliću žalosna ti majka,/ Neš se dugo Poglavnikom zvati/ Sve zbog tvoga krvavog terora,/ Što ga Srbin pretrpeti mora/ Srbin znade osvetiti brata/ Jači tada je od dvesta Hrvata!/ Bolje da se sami povešate,/ Neg Srbina živa dočekate,/ Ciganka je porodila bika, Glava mu je ko u Poglavnika!“"66

Represivni organi, kao što smo uočili, nisu samo operativnim radom dolazili do osoba koje su vršile antiokupatorsku propagandu. Dostave koje su obični građani upućivali iz najrazličitijih pobuda otkrivale su one koji govore protiv režima. Otpuštanje jednog zaposlenika koštalo je slobode Fabijana Sorislava, vlasnika kafane „Zlatni jelen“ u Ulici prestolonaslednika br. 8. Konobar Ljuba Antonijević, nezadovoljan postupkom svog poslodavca, pristupio je samostalno pred islednike Gestapoa 27. aprila 1942. i izjavio da Sorislav „psuje firera“, da je otišao tako daleko „da mu je psovao majku“, da je prilikom paradiranja folksdojčerske omladine u maju 1941. izjavio da je to dokaz kako Nemačka više nema odraslu vojsku. Kafedžija Sorislav je priveden 4. maja 1942, ali je na saslušanju opovrgao optužbe. Islednici nisu bili spremni da mu poveruju, jer je to bio drugi put kako je hapšen zbog kritikovanja okupacione vlasti. U zaključnom izveštaju od 7. maja 1942. predloženo je da se pošalje na prinudni rad u Norvešku. Iz pritvora je sproveden u logor na Sajmištu, a odatle u Norvešku 9. maja 1942. ${ }^{67}$

Tokom okupacije u Beogradu bilo je veoma rizično razgovarati za kafanskim stolom o politici, jer je bilo doušnika. Đorđe Brkić i Mladen Mrvoš su

\footnotetext{
${ }^{64}$ Isto.

${ }^{65}$ Logor Banjica, I, 347.

${ }^{66}$ Citirano prema: Aleksandar Vojinović, NDH u Beogradu (Zagreb: Naklada Pavičić, 1995), $108,145$.

${ }^{67}$ IAB, BDS, F-121, Fabijan Sorislav.
} 
31. jula 1942. u kafani, u prisustvu Dušana Stojkovića, obučenog u nemačku uniformu, pomislivši da je Nemac i da ne zna srpski jezik, izjavili: „J...m Hitlera, njegovu vojsku i čitav Nemački narod! J...m uniformisanu mladež, koja se bori protiv komunista. Komunisti u Rusiji će uskoro ustati i mi se nadamo, da će uskoro biti uništena cela Nemačka. U Srbiji su takođe ustali komunisti, oni će uskoro objesiti sve Nemce i mi Srbi ćemo tada pokazati, što može učiniti cela Srbija“. ${ }^{68}$ Pred organima Gestapoa pokušavali su da odglume ,,selektivnu amneziju“, prouzrokovanu prekomernom upotrebom alkohola. Priterani uza zid od strane islednika, Mrvoš i Brkić priznali su „delo“. Okupator je u ovom slučaju bio blag i prihvatio je predlog uhapšenih koji su radili za Vermaht da doniraju nemačkom Crvenom krstu 50.000 dinara. ${ }^{69}$

Slučajan susret na ulici 17. avgusta 1942. drugova iz Vojne akademije Radovana Radovića, inženjerskog poručnika i Nikole Joksimovića, kapetana I klase nije protekao srdačno i prijateljski. Posle kurtoaznog razgovora Radović je upitao zašto je Joksimoviću uvijena ruka, na šta je dobio objašnjenje da je ovaj oficir Srpske poljske straže ranjen u borbi protiv komunista. Radović je potom konstatovao: „Za to te ne žalim i što si tražio to si i dobio“". ${ }^{70}$ Uzalud je Joksimović molio druga sa klase da tako ne govori jer ga „dira u samo srce“, budući da je u „,borbi protiv komunista bio punih šest meseci kao komandant odreda". Kako je Radović ostao pri svom stavu, Joksimović ga je uhapsio i priveo u Specijalnu policiju. Na saslušanju Radović je izjavio kako je sve počelo kao šala i nesporazum, koji se pretvorio u otvoren sukob. Posle procene da poručnik Radović nije komunistički orijentisan, islednici su doneli odluku o njegovom puštanju na slobodu 4. septembra $1942 .^{71}$

U drugoj polovini 1942. postalo je jasno da Vermaht nije nepobediv $\mathrm{i}$ da parola „Nemačka pobeđuje na svim frontovima“ nije više aktuelna. „Loš“ glas stigao je i do Beograđana, koji su ohrabreni tim vestima pojačali antiokupatorsku retoriku. O razmerama širenja zabranjenih vesti u Beogradu i metodama koje je okupacioni sistem koristio prilikom suzbijanja takve delatnosti svedoči rad represivnih organa u drugoj polovini 1942. U septembru je Uprava grada Beograda sprovela veliku akciju hapšenja lica koja su širila ,alarmantne vesti“. Otkriveno je i uhapšeno ukupno 20 građana, koji su nakon istrage sprovedeni u logor na Banjici i osuđeni na „dnevni prinudni rad“. Među uhapšenima su bili mehaničari, jedan direktor, pekari, činovnici i ljudi drugih profesija, što je pokazatelj da su u širenju vesti učestvovali svi slojevi beogradskog društva. U cilju zastrašivanja o celokupnom slučaju upoznata je javnost preko dnevne štampe, a objavljena su i imena uhapšenih kako bi propagandni deo akcije bio što efektniji. $^{72}$ Tokom novembra po istom osnovu uhapšeno je 21 lice, a akcija je u istom tonu propagandno eksploatisana kroz kolaboracionističku štampu. ${ }^{73}$

\footnotetext{
${ }^{68}$ IAB, BDS, B-640, Đorđe Brkić; IAB, BDS, reg. br. 5, Ben-Blu.

69 Isto.

${ }^{70}$ IAB, UGB, SP, IV-9/ 60.

71 Isto.

72 „Лица ухапшена због ширења алармантних вести“, Ново време, 20. 9. 1942, 5.

73 „Лица ухапшена због ширења алармантних вести“, Обнова, 14. 11. 1942, 5.
} 
Ovakve mere nisu obeshrabrile Beograđane koji su nastavili sa protivokupatorskom retorikom. Zastoj jedinica Vermahta pred Staljingradom bio je predmet ismevanja u ovom periodu. Na dan 24. oktobra 1942. Beograđanin Dragutin Ranković beleži u svoj dnevnik da se po kuloarima prepričava sledeća anegdota: „1) Staljingrad pao - u zaborav./ 2) Nemci kupe stolice po Beogradu/ - Šta će im? Pitaju./ - Da sede kod Staljingrada pošto će tamo prezimeti““74

U najvećoj opasnosti da budu otkriveni zbog verbalnog delikta nalazili su se muzičari koji su za svoju dušu ili kako bi zadovoljili svoje mušterije svirali i pevali pesme koje nisu prijale „ušima“ okupatora. U neprilici ove vrste našao se bend poetičnog naziva „Lumpacijus vagabundus“. U novembru 1942. članovi benda prijavljeni su od strane kafedžije Mihaela Sofleka da su nastupajući u ,varijateru kod Bajlonija“ u repertoaru imali i pesme koje su veličale kralja Petra II Karađorđevića, slavile „boljševike kod Staljingrada“, kritikovale Nemačku. Izvedeni na saslušanje pred nemačku policiju 16. novembra Kosta Ćirkov radijski pevač, Slobodan Strajnić operski pevač i Ljubomir Radulović priznali su da su na slavljima na zahtev gostiju svirali i pevali zabranjene pesme. Ovaj trio se potrudio i da narodne pesme, poput sevdalinke ,72 dana“, iskoristi na taj način što ih je ubacivanjem novih reči prilagođavao i od ljubavnih pravio političke. Na sreću Beograđana koji su uživali u njihovoj muzici, ali najviše samih članova, bend je pušten 18. novembra 1942. na slobodu uz upozorenje o daljem ponašanju. ${ }^{75}$

Okupacija je narušila mnoge međuljudske odnose. Posebno su se osećale napetosti između folksdojčera koji su se u velikoj meri uključili u okupacioni režim i većinskog srpskog stanovništva. U januaru 1943. sodadžija Ana Šmid prijavila je nemačkoj policiji svog komšiju Radivoja Crvenovića, zbog psovki upućenih na ,njen račun“, na račun Nemaca i Adolfa Hitlera. Ono što je posebno iziritiralo ovu folksdojčerku da prijavi Crvenovića je činjenica što nije postojao nijedan lični razlog za njegovo ponašanje i što mu je čak pomagala materijalno. Njene navode potvrdili su policijskim službenicima Dragoslav Milovanović i Dragica Selić koji su stanovali u istoj zgradi. Gestapo je sproveo istragu, uhapsio optuženog i „doneo presudu“ da Radivoja Crvenovića pošalju u Mauthauzen. U logoru ovaj sezonski radnik nije izdržao ni godinu dana, jer je prema zvaničnim podacima preminuo 11. decembra 1943. od encefalitisa (upale mozga). ${ }^{76}$

Jedinice Crvene armije slamale su poslednji otpor Vermahta pred Staljingradom u februaru 1943, a porazi nemačke vojske unosili su radost u domove Beograđana. Prilikom rutinskog pretresa na ulici jedan službenik XI kvarta UGB pronašao je u džepu Olivere Todorović sledeću pesmu: „Na istočnom frontu pada krupan sneg, Hitlerova vojska danas je u beg. Zbogom ruski frontu, Hitleru je zort $^{77}$ ، "78 Imenovana je predata organima Specijalne policije. Prema zapisniku od

\footnotetext{
74 Драгољуб Ј. Ранковић, Свакодневни живот под окупаиијом. Искуство једног Београђанина 1941-1944, пр. Наташа Милићевић и Душан Никодијевић (Београд: Институт за новију историју Србије, 2011), 360, 361.

${ }^{75}$ IAB, BDS, C-239, Kosta Ćirkov.

${ }^{76} \mathrm{IAB}, \mathrm{BDS}$, reg. br. 55, Sa-Sch.

77 Zort (turcizam): zebnja, strah, strahopoštovanje itd.

${ }^{78}$ IAB, UGB, SP, IV-170/84.
} 
24. februara 1943. pesmu je čula od jednog prolaznika i jedne devojčice i potom je zapisala kako bi bratu od tetke Antonu Černom, nemačkom podoficiru, ,pokazala kakve sve stvari izmišljaju komunisti“". Nismo uspeli da dođemo do podataka da li su islednici poverovali Todorovićevoj i pustili je na slobodu. ${ }^{79}$

Muziciranje svirača $u$ sredstvima javnog prevoza praktikovano je i tokom okupacije u Beogradu. Jedan od uspešnih uličnih harmonikaša sa višedecenijskim iskustvom koji je i pod okupacijom nastavio da radi bio je Aleksa Antonijević. Ovaj slepi samouki muzičar svirao je putnicima po kupeima vozova koji su saobraćali kroz Beograd. Svoj repertoar Antonijević je pod okupacijom obogatio pesmama u kojima se veličaju Ravnogorski pokret i general Dragoljub Mihailović, i kritikuje okupaciona uprava. Službenici Specijalne policije dobili su informaciju o ovom slučaju 31. marta 1943. i uhapsili Antonijevića. Na saslušanju muzičar je priznao sve optužbe, ali je uz upozorenje i zabranu da svira po vozovima pušten na slobodu. ${ }^{80}$

Ljudi iz uglednih porodica vršili su takođe prekršaje iz oblasti verbalnog delikta. Jedan od njih bio je Dragomir Čurković, sin bivšeg predsednika beogradske opštine. U avgustu 1943. ovaj advokat je napuštajući gostionicu „Gal“ pozdravio prisutne rečima „Zbogom peta kolono“. Munjevito je reagovao jedan stražar i uhapsio ga na licu mesta. Straža ga je sprovela Gestapou i izveden je na saslušanje 19. avgusta. Pred islednicima je priznao krivicu i upućen je u logor na Banjicu, odakle je od strane okupatora odveden u nepoznatom pravcu 13. jula $1944 .{ }^{81}$

Ne znamo da li narodna izreka „što trezan misli pijan govori“ može da se odnosi i na Radomira Obradovića, ali nesumnjivo da su ga reči izgovorene tokom pijanstva dovele u nepriliku. Usled siromaštva ovaj prodavac knjiga bio je prinuđen da se hrani i namirnicama koje su građani, iz običaja, ostavljali pored grobova svojih bližnjih na Novom groblju. Pored hrane bilo je i alkohola, te je Obradović 15. septembra 1943. popio „koju čašicu više“ i krenuo u centar grada. Prolazeći Terazijama, počeo je da uzvikuje: „Policija j...m Vam majku“ i „Živela Sovjetska Rusija“. Odmah je uhapšen od strane jednog nemačkog vojnika i predat agentu Specijalne policije. Izveden pred islednike 15. septembra 1943, ,otrežnjene glave“, izjavio je da je na Novom groblju „od mnogih ljudi i žena dobijao i rakije i vina“, da je „od mešavine i velike količine alkohola bio totalno pijan“, te da se ne seća izgovorenih reči. Policija je rešila da mu progleda kroz prste i istog dana je pušten. ${ }^{82}$

I nesuglasice između supružnika pomagale su okupatoru da sazna ko nije „oduševljen“ njegovom upravom. Kako bi izdržavala svoju porodicu Lidija Jakšić je prala veš nemačkim vojnicima, što se nije svidelo njenom nevenčanom suprugu Iliji Mihailoviću, lučkom radniku koji je praktikovao da bračne razmirice rešava nasiljem. Ogorčeni suprug optuživao je Jakšićevu da ima ,spolne odnošaje“ sa vojnicima, izražavao svoj prosovjetski i antinemački stav, pretio da se neće smiriti dok ne liši života jednog Nemca. U novembru 1943. ova Beograđanka je ceo slučaj pri-

\footnotetext{
${ }^{79}$ Isto.

${ }^{80}$ IAB, UGB, SP, III-38/1, k. 155.

${ }^{81}$ IAB, BDS, reg. br. 11, Č-Ć.

${ }^{82}$ IAB, UGB, SP, IV-25/117.
} 
javila Gestapou. Njene navode potvrdile su komšije Živka i Husein Nasifović. ${ }^{83}$ Ovaj lučki radnik uhapšen je i saslušan, a 22. novembra 1943. poslat u logor na Banjici. Iz logora je 11. februara 1944. odveden u rudnik Bor na prinudni rad. ${ }^{84}$

Ispred sedišta Specijalne policije na Obilićevom vencu Beograđani su uvek mogli da susretnu službenike ovog dela represivnog aparata okupacione uprave. Prilikom jednog od ovakvih susreta 14. februara 1944. novinar Božidar Mandić, posle konzumiranja nekoliko čašica rakije, okuražio se da umesto uobičajenog ,Dobar dan“ grupi policajaca dobaci: „Vi ste krivi za sva zla koja su nas zadesila“. Na upozorenje agenta Milovana Popovića da obrati pažnju kako se ponaša, novinar je drsko odgovorio: „Šta, da nećete da me vodite u Upravu?". Posle takvog nastupa Mandić je lišen slobode i izveden pred dežurnog islednika Specijalne policije. Ukazivanjem na svoju predratnu karijeru prilikom koje je pisao za nacionalne listove i tajno radio kao obaveštajac bana Dunavske banovine u praćenju „mađarske nacionalne manjine“, ali i na mentalnu nestabilnost, Mandić se spasao upućivanja u logor na Banjici. ${ }^{85}$

Antiokupacionu, prosavezničku i prokomunističku propagandu vodio je u aprilu 1944. i radnik Milan Šinik. Uputivši se u Opštu bolnicu 25. aprila kako bi njegov cimer Milan Drvenica sanirao povrede dobijene tokom savezničkog bombardovanja, ugledao je grupu ljudi ,sa fesovima koji su bili čuvani od strane Ustaša“". ${ }^{86}$ Započeo je razgovor sa nepoznatom osobom iz te grupe, kojoj je rekao „da svi idu u šumu, da imaju pravo oni što bombarduju“, da bi on počeo da ubija na ulici da je bombardovanje trajalo još dva dana; uz to, afirmativno je govorio o Karlu Lukaču, članu KPJ i atentatoru na starešinu kvarta Uprave grada Beograda Dragoljuba Šterića. ${ }^{87}$ Šinik nije znao da je njegov sagovornik agent antikomunističkog odseka Blagoje Dragić. Na saslušanju od 27. aprila priznao je da je izgovorio reči koje mu se stavljaju na teret, ali je pokušao da popravi svoj položaj navodeći da su mu vlasti NDH ubile brojne članove porodice i da se njegovo izlaganje odnosilo na ustaše. Ne znamo da li je njegova odbrana ili haotično stanje koje je posle savezničkog bombardovanja zahvatilo domaću upravu uticalo da dobije „,blaži tretman“, ali Šinik je kažnjen samo sa tri dana prinudnog rada na raščišćavanju ruševina. ${ }^{88}$

Savezničke bombe koje su padale po beogradskim ulicama od prve polovine 1944. nametnule su bombardovanje kao temu razgovora među građanima. Jedna od ovakvih konverzacija povela se u gostionici „Romanija“ u junu 1944. između pripadnika Ruskog zaštitnog korpusa Jakoba Alpatova, vlasnice ovog ugostiteljskog objekta folksdojčerke Elizabete Kučković i pojedinih gostiju. Alpatov je tvrdio da će

\footnotetext{
${ }^{83}$ IAB, BDS, reg. br. 27, Ja-Jaz.

${ }^{84}$ Logor Banjica, II, 385.

${ }^{85} \mathrm{IAB}, \mathrm{UGB}, \mathrm{SP}, \mathrm{IV}-53 / 34$.

${ }^{86}$ Nismo uspeli da proverimo navode Šinika o prisustvu naoružanih ustaša u Beogradu tokom okupacije. Isključujemo i mogućnost da su nakon savezničkog bombardovanja logora na Sajmištu zatočenici upućivani u pratnji ustaša u Opštu bolnicu, jer je ovaj logor od vlasti NDH preuzet 17. maja, a događaj koji Šinik opisuje odigrao se 27. aprila 1944.

${ }^{87}$ IAB, UGB, SP, IV-28/ 244.

${ }^{88}$ Isto.
} 
avioni Crvene armije početi bombardovanje iz Rumunije i Bugarske, kako bi zaplašio Kučkovićevu. Ovaj beloemigrant demonstrirao je i sovjetski pozdrav dizanjem stegnute pesnice, na šta je reagovao jedan stražar i uhapsio ga. Ubrzo je na poziv vlasnice lokala došla nemačka patrola i odvela Alpatova. Nismo uspeli da saznamo da li je Alpatov odveden u logor ili je imao priliku da u praksi isproba pozdrav i dočeka crvenoarmejce nekoliko meseci kasnije u oslobođenom Beogradu. ${ }^{89}$

Ime prvog čoveka komunističkog pokreta otpora Josipa Broza Tita bilo je u velikoj meri zastupljeno u javnosti. Uporedo sa kritikama kolaboracionističke štampe, Brozovo ime je po kuloarima bilo i sinonim za osvetnika koji će se obračunati sa nosiocima okupacione vlasti. ${ }^{90}$ Ovakvu percepciju Brozove ličnosti negovali su i pojedini državni službenici poput Đorđa Radoševića, činovnika Centralne blagajne finansijske kontrole, koji je 22. juna 1944. na ulici pred okupljenim sugrađanima „psovao srpstvo i vladu“. Prišao mu je jedan od stražara na šta je Radošević zapretio: „Tito će vam svima doći glave“, nakon čega je lišen slobode. Izveden na saslušanje pred islednike Specijalne policije 23. juna, ovaj 52-godišnji Beograđanin je izjavio da je tog dana toliko konzumirao alkohol da se ne seća šta je govorio. Islednici su zaključili da je on ,star čovek i ne ostavlja utisak da je komunistički orijentisan“, pa su doneli odluku da puste Radoševića na slobodu. ${ }^{91}$

\section{Časovničar i učiteljica}

Pojedini Beograđani cenili su slobodu govora više od sopstvenog života. Jedan od poznatih primera je Aleksandar Ignjatović. ${ }^{92}$ Ovaj sajdžijski šegrt radio je $\mathrm{u}$ međuratnom periodu u časovničarskoj radnji folksdojčera Mihaela Šumahera. Prema svemu sudeći Ignjatović je voleo da razmenjuje političke stavove i u svom bivšem poslodavcu je tokom okupacije pronašao adekvatnog sagovornika. Ignjatovićeva interpretacija trenutnih vojnih i političkih događaja nije prijala ušima njegovog kolege, šegrta Ota Rigera. Ovaj folksdojčer prijavio je Gestapou 17. septembra 1941. da je čuo Ignjatovića kako Šumaheru govori „da je ispravno da se u šumi nalaze Srbi, koji streljaju nemačke vojnike“, da je želeo da položi opkladu da će „Rusi stajati pred Berlinom", da je kritikovao nedostatak i visoke cene osnovnih životnih namirnica, da su zvanični izveštaji sa Istočnog fronta neistiniti i tome slično. Pozvani da daju izjavu povodom ovih navoda, Šumaher i šegrt Franc Dragićević potvrdili su priču Rigera. Istog dana Ignjatović je uhapšen i izveden na saslušanje. Nakon

\footnotetext{
${ }^{89}$ IAB, BDS, reg. br. 33, Kro-Ku.

${ }^{90}$ Rade Ristanović, „Komunistička neman: izveštavanje kolaboracionističke štampe o Narodnooslobodilačkom pokretu“", u: Kolaboracionistička štampa, 2015, 24, 27.

${ }^{91}$ IAB, UGB, SP, IV-40/395.

${ }^{92}$ Aleksandar Ignjatović je rođen 4. februara 1921. u Somboru. Po napuštanju srednje škole postao je sajdžijski šegrt u Šumaherovoj radnji. Posle dve godine napustio je ovog majstora i radio u više časovničarskih radionica. Pod okupacijom radio je u radnji Ace Jankovića u Krajinskoj ulici. Savremenici ovog mladića opisuju kao čoveka vedrog duha, pravdoljubivog, sportistu i ljubitelja pisane reči. Živeo je u višečlanoj porodici, imao je dva brata i sestru. Prve probleme sa okupacionim vlastima imao je u avgustu 1941, kada je uhapšen pod sumnjom da je hteo da pomogne Vasiliji Stamenković, komunističkoj ilegalki koja je uhvaćena prilikom paljenja novina na ulici. Nakon saslušanja pušten je na slobodu. MŽG, ZBB, cd br. 6.
} 
davanja osnovnih biografskih podataka, ovaj 20-godišnji mladić je na pitanja islednika po predmetu hapšenja izjavio sledeće: „Jeste li vi kazali, da je pobeda Rusije sigurna, jer na njenoj strani stoje Engleska i Amerika?/ Da./ Jeste li vi kazali, da slušate moskovske i nemačke radio stanice, da bi tako istražili istinitost izveštaja?/ Da. No ja sam ne slušam moskovsku radiostanicu. Ove izveštaje mi daje jurista Mita Siečanski [...]/ Jeste li vi kazali da nalazite ispravno, što Srbi vrše akte sabotaže i streljaju nemačke vojnike?/ Ne. Ja sam rekao, da držim ispravnim, što Srbi vrše akte sabotaže i miniraju vozove. [...]/ Da li vas je Šumaher pitao kakvu svrhu ima, što komunističke bande u Beogradu i van Beograda ubijaju nemačke vojnike?/ Da./ Sta ste vi na to odgovorili?/ Ja sam na to odgovorio, da se ovo ne događa samo ovde, nego u čitavoj okupiranoj Evropi./ Jeli vam Šumaher rekao, da se za svakog Nemca strelja 50 komunista?/ Da/ Zašto vam je Šumaher ovo rekao?/ Jer sam ja Šumaheru pre toga rekao, da je ispravno da se nemački vojnik ubija./ Zašto niste odmah priznali, da ste kazali da je ispravno, da Srbi ubijaju nemačke vojnike?/ Ja imadem strah da ću biti streljan./ Jeste li rekli da se ubijanjem nemačkih vojnika oštećuje Nemački Vermaht i da je to vama pravo?/ Da [...]/ Jeste li kazali, da Ribentropa ništa ne košta, ako on zamoči pero i umesto 10.000, 100.000 tona navede kao potopljenu borsku tonažu?/ Ne, ovo nisam rekao o Ribentropu, nego o Gebelsu [...]/ Imate li veze sa komunistima ili sa licima, koja su jednako raspoložena kao i vi?/ Ne./ Iz kojeg razloga vodite takve razgovore?/ Zato, što ne verujem, da će Nemačka pobediti [...]/Zašto ste tako govorili?/ Jer sam Šumaheru ovim mojim stavom hteo da razume, da Nemačka neće nikada pobediti [...]/ Zar ste u Srbiji želeli ruskokomunističke prilike?/ Ne./ Zašto ne?/ Jer ne volim diktature i više sam za demokratiju./ Zašto smatrate da je ispravno, da se u Srbiji vrše akti sabotaže i ubijaju nemački vojnici?/ Jer će na ovaj način brže propasti borbena snaga Nemačke./ Jeste li svesni toga, da je to komunistička propaganda i huškanje stanovništva protiv okupacione armije?/ Da."93

Ovakav iskaz bio je dovoljan islednicima da zaključe „da je on time proigrao svoj život“ i da ga „treba prebaciti za iduću egzekuciju“ ${ }^{94}$ Uzalud je Ignjatovićeva majka Ana ukazivala Gestapou da njen sin ,nije nikada pripadao bilo kakvoj političkoj partiji“ i „da je iz čiste mladalačke lakomislenosti i želje da oponira svome bivšem majstoru izgovorio nepovoljne reči o nemačkoj nepobedivoj armiji“, okupator nije pravio razliku - ovaj mladić izveden je 29. septembra iste godine pred streljački vod. Posleratne vlasti sprovele su istragu 1952. povodom ovog slučaja. Oto Riger je uhapšen i osuđen na kaznu strogog zatvora u trajanju od 15 godina i „ograničenje građanskih prava“. ${ }^{95}$ Odlukom Saveza boraca Aleksandar Ignjatović je 29. novembra 1950. dobio Spomenicu, uprkos činjenici što ne postoje čvrsti materijalni dokazi da je bio deo NOP-a. ${ }^{96}$

\footnotetext{
${ }^{93}$ IAB, BDS, I-38, dosije Aleksandar Ignjatović.

${ }^{94}$ Isto; MŽG, ZBB, cd br. 6; Branislav Božović, „Dosje I-38“, 13. maj/1967, XX/ 3, 21-41.

${ }^{95}$ MŽG, ZBB, cd br. 6.

${ }^{96}$ Herojstvo Aleksandra Ignjatovića dobro je poznato i dokumentovano u istoriografiji i publicistici, a bilo je i motiv jedne epizode igrane serije „Otpisani“. Ono što povezuje sve ove činioce jeste interpretacija da je ovo delo bilo sastavni deo otpora koji je pružala KPJ. Činjenica da istraživači nisu ponudili čvrst dokaz da je Ignjatović bio deo ovog pokreta otpora i da je prili-
} 
Umesto da mirno provodi svoje penzionerske dane učiteljica $\mathrm{u}$ penziji Leontina Kraus, ${ }^{97}$ vođena ,devizom“ da „,komunističko uređenje u svetu jedino može da pruži ljudima ravnopravnost“ i da „vodeće državničke ličnosti ne vode pravu narodnu politiku“, uputila je niz pisama predsedniku kolaboracionističke vlade Milanu Nediću. Ukazivala je Nediću na pogubnu politiku okupacione uprave čijim je članovima dodelila epitet „obezumljeni upravljači“, zahtevajući njegovo povlačenje i prepuštanje vlasti komunistima. U pojedinim pismima imala je molbu za prvog čoveka kolaboracionističke uprave: „Molim da oslobodite najmlađeg komunistu osuđenog na smrt streljanjem, a na njegovo mesto da se stavi mene“. Pismo od 11. decembra 1942, u kojem je ponovila molbu da je odvedu na streljanje, bila je „kap koja je prelila čašu“. Na marginama pisma šef kabineta predsednika vlade Miloš Masalović rukom je napisao poruku za šefa Specijalne policije Iliju Paranosa: „Evo još lepe književnosti ja mislim da je treba poslušati, ne znam šta ti i g. Bećar (Božidar Bećarević - prim. R. R.) mislite“.

Policija je uhapsila i saslušala Krausovu 17. decembra 1942. Prilikom saslušanja ova učiteljica je ponovila sve navode iz pisama. Referent IV odseka Specijalne policije koji je vodio slučaj konstatovao je „da je idejno izgrađena i fanatizovana komunistkinja, ali da nije opasna po javni red i mir, pošto svoja ubeđenja ne izlaže pred drugima, niti je organizovana u Komunističku partiju“. Upućena je 20. decembra 1942. u logor na Banjicu da „ostane do dalje odluke vlasti“, kao krivac I kategorije. U logoru je provela šest meseci i 15 dana, da bi 7. juna 1943. bila izvedena na streljanje. ${ }^{98}$

\section{Zaključak}

Nastojanja nemačkog okupatora da hermetički zatvori okupirani prostor za protok informacija čime bi onemogućio da se Beograđani informišu uz pomoć drugih kanala nisu urodila plodom. Građani prestonice slušali su intenzivno zabranjene radio-stanice i informacije „po kuloarima“ prenosili usmenim putem. Okupator, kolaboracionisti, saveznici, pokreti otpora i zločini u NDH bile su dominantne teme u beogradskom ilegalnom diskursu. Pojava narodnih pesnika koji pišu pesme sa političkom konotacijom bila je u skladu sa tradicijom srpskog na-

kom saslušanja on decidirano izjavio kakvo je njegovo političko i ideološko opredeljenje, opredelila nas je da ovaj događaj interpretiramo kao individualni oblik otpora. Iskrenost prilikom isleđenja po drugim pitanjima ne ostavlja mnogo prostora za tezu da se na ovaj način samo prikrivao tokom istrage. Гојко Лађевић и други, Београд у рату и револуиији 1941-1945, 1, (Београд: Историјски архив Београда, 1984), 301, 302; MŽG, ZBB, cd br. 6.

${ }^{97}$ Leontina Kraus je rođena 16. aprila 1881. u Pišćanoviću (srez Novi Marof). Još kao šestogodišnja devojčica upućena je u samostan Milosrdnih sestara u Zagrebu, gde je završila učiteljsku školu. Prvo postavljenje dobila je 1903. u Rumi, a zatim je služila po raznim mestima u Hrvatskoj neprekidno do 1921. kada je penzionisana kao komunistički orijentisana. U Beograd dolazi 1930, upisuje Filozofski fakultet koji završava 1939. Glad za znanjem odvodi je na Pravni fakultet, ali školovanje na ovoj visokoškolskoj ustanovi prekida joj Aprilski rat 1941. Prema sopstvenom priznanju nikada nije bila pripadnik nijednog ilegalnog pokreta, ali je u komunističkoj ideologiji videla rešenja koje će dovesti do jednakosti među ljudima. IAB, UGB, SP, IV-Q-12/133; IAB, BDS, reg. br. 33, Kro-Ku.

98 Jedna ulica na beogradskoj opštini Voždovac nosi ime „Učiteljice Leontine Kraus“. Logor Banjica, I, 599. 
roda. I u ovom periodu beogradske kafane su služile kao svojevrsne novinske agencije gde su se dobijale najrazličitije informacije ili slušale zabranjene pesme. Izvori na kojima su Beograđani mogli da se napajaju zabranjenim informacijama bili su i pijace, ulica, krsne slave i druga mesta okupljanja gde su vođeni neformalni razgovori. Individualni primeri kršenja verbalnog delikta poput časovničara Aleksandra Ignjatovića i učiteljice Leontine Kraus svedoče da je među Beograđanima bilo ljudi koji se nisu plašili represivnih mera i pretnji okupatora i koji su izgubili život kako bi odbranili dignitet stanovništva okupirane Srbije.

Okupator je od prvog dana objavio da će slušanje zabranjenih radio-stanica i protivokupatorsku propagandu najstrože kažnjavati. Kako bi se ova pojava suzbila i prekršioci pronašli, policijske i bezbednosne strukture koristile su mrežu poverenika i službenika na terenu. Veliki broj ljudi otkriven je denuncijacijama koje su većinom bile motivisane ličnim razlozima. Navedeni primeri svedoče da su uhapšenici nakon istrage streljani ili odvođeni u logore smrti i prinudne logore samo zbog reči koje su saopštili ili informacija koje su sakupili, ali i da su pojedinci puštani na slobodu ili „osuđivani“ na kraće kazne, što govori da nije postojao jasan kriterijum okupacionog sistema prilikom kažnjavanja. Pored operativnih akcija, okupator je delovao preventivno koristeći propagandna sredstva. Na ovaj način režim je nastojao da one koji šire zabranjene informacije ili nameravaju da to čine zaplaši i odvrati od takve aktivnosti. Sinhronizovane akcije represivnog i propagandnog aparata su dobar pokazatelj da je prema procenama okupacionog sistema veliki broj ljudi slušao zabranjene radio-stanice i kršio verbalni delikt.

Uprkos činjenici što slušanje zabranjenih radio-stanica i kršenje verbalnog delikta nije bilo u direktnoj funkciji ostvarivanja savezničkih vojnih ciljeva, ovakav oblik neoružanog i civilnog otpora u Beogradu bio je od višestruke važnosti. Pre svega istakli bismo njegovu moralnu vrednost. Ovakva delatnost predstavljala je glavnu branu protiv okupatorovih nastojanja da uguši fundamentalne vrednosti jednog društva, poput slobode govora $\mathrm{i}$ informisanja. Antiokupatorska retorika kompromitovala je režim i njeno širenje je negativno uticalo na težnju okupatora da upotrebom propagande zadobije podršku stanovništva, što je bio jedan od glavnih preduslova za pacifikaciju i eksploataciju okupirane teritorije. Spontano širenje vesti u kojima se kritikuje okupator, ističu pobede savezničkih snaga i porazi Vermahta bilo je podjednako važan faktor i za afirmisanje organizovanog otpora među stanovništvom. Upijanje ovih vesti moglo je da utiče na Beograđane da odu u ,ک̌umu“, uključe se u gradske organizacije, ili da kao simpatizeri novčano i materijalno pomažu pokretima otpora.

\section{REFERENCE}

- Aleksić, Dragan. „Površina i broj stanovnika na području vojnoupravnog komandanta Srbije“. Tokovi istorije, br. 4, (1999), 144-150.

- Begović, Sima. Logor Banjica 1941-1944. I, II. Beograd: Institut za savremenu istoriju, 1989. 
- Božović, Branislav. Specijalna policija u Beogradu 1941-1944. Beograd: Prosveta, 2003.

- Brayant, Chad. "The Language of Resistance Czech Jokes and Joke-telling under Nazi Ocuppation, 1943-1945”. Jurnal of Contemporary History, vol 41, (1), 133-151. https://doi.org/10.1177/0022009406058687

- Čulinović, Ferdo. Okupatorska podjela Jugoslavije. Beograd: Vojnoizdavački zavod, 1970.

- Dimitrijević, Bojan. „General SS i policije August Majsner i srpski sistem bezbednosti 1942-1943“. Istorija 20. veka, br. 3, (2010), 69-83.

- Jevtović, Miroljub. Šta kaže Radio London. Beograd: A-Š delo, 1989.

- Kallis, Aristotel A. Nazi Propaganda and the Second World War. New York: Palgrave Macmillan, 2005. https://doi.org/10.1057/9780230511101

- Kolaboracionistička štampa u Srbiji 1941-1944. 1. Ur. Aleksandar Stojanović. Beograd: Filip Višnjić, 2015.

- Kolaboracionistička štampa u Srbiji 1941-1944. 2. Ur. Aleksandar Stojanović. Beograd: Filip Višnjić, 2017.

- Koljanin, Milan. „Represija kao sistem - logori u okupiranoj Srbiji 19411945“. Hereticus, br. 1, (2007), 157-171.

- Koljanin, Milan. „Struktura i delovanje policije nacističke Nemačke u okupiranoj Srbiji 1941-1944“. Istorija 20. veka, br. 3, (2011), 143-156. https://doi.org/10.29362/ist20veka.2011.3.kol.143-156

- Koljanin, Milan. Nemački logor na beogradskom Sajmištu 1941-1944. Beograd: Institut za savremenu istoriju, 1992.

- Kreso, Muharem. Njemačka okupaciona uprava u Beogradu 1941-1944. Beograd: Istorijski arhiv Beograda, 1979.

- Lađević Gojko, i drugi. Beograd u ratu i revoluciji 1941-1945. Beograd: Istorijski arhiv Beograda, 1984.

- Logor Banjica: Logoraši, knjige zatočenika Koncentracionog logora Beograd-Banjica 1941-1944, I-II. Prir. Evica Micković i drugi. Beograd: Istorijski arhiv Beograda, 2009.

- Michel, Henri. The Shadow War: European Resistance 1939-1945. New York: Harper \& Row, 1972.

- Mraović Marijana, „Propaganda vlade Milana Nedića (1941-1944)“. Doktorska disertacija, Univerzitet u Beogradu, Filozofski fakultet, Odeljenje za istoriju, 2015.

- Nemačka obaveštajna služba, IV. Beograd: Državni sekretarijat za unutrašnje poslove, 1959.

- Nikolić, Mirjana. Sender Belgrad Okupacijski Radio Beograd Zender Belgrad: Radiofonija u Srbiji tokom Drugog svetskog rata. Beograd: Radio Beograd, 2009.

- Ranković, Dragoljub J. Svakodnevni život pod okupacijom. Iskustvo jednog Beograđanina 1941-1944. Prir. Nataša Milićević, Dušan Nikodijević. Beograd: Institut za noviju istoriju Srbije, 2011.

- Ristanović, Rade. „Svakodnevica prvih meseci okupacije u člancima Beogradskih opštinskih novina“. Istorija 20. veka, br. 2, (2014), 95-110. https://doi.org/10.29362/ist20veka.2014.1.ris.95-110 
- Ristanović, Rade. „Oblici otpora u okupiranom Beogradu 1941-1944“. Doktorska disertacija, Univerzitet u Novom Sadu, Filozofski fakultet, Odeljenje za istoriju, 2019.

- Ristović, Milan. Nemački novi poredak i Jugoistočna Evropa: 1940/41-1944/45: planovi o budućnosti i praksi. Beograd: Vojnoizdavački i novinski centar, 1991.

- Stargardt, Nicholas. The German War: A Nation under Arms. London: Penguin Random House, 2015.

- Stefanidis, Ioannis. Substitute for Power: Wartime British Propaganda to the Balkans. 1939-44. Farnham: Ashgate Publishing Limited, 2012.

- Stenton, Michael. Radio London and Resistance in Occupied Europe: British Political Warfare 1939-1943. Oxford: Oxford University Press, 2000. https://doi.org/10.1093/acprof:oso/9780198208433.001.0001

- Stokker, Cathleen. Folklore Fights the Nazis: Humor in Occupied Norway 1940-1945. Madison: The University of Wisconsin Press, 1997.

- Terzić, Milan. „Delatnost radio stanice „Karađorđe“ u Jerusalimu“. Zbornik Matice srpske za istoriju, br. 88, (2013), 57-71.

- Vlahović, Veljko. Borba za slobodnu Jugoslaviju. Beograd-Titograd: Komunist-Pobjeda, 1981.

- Vojinović, Aleksandar. NDH u Beogradu. Zagreb: Naklada Pavičić, 1995.

-Welch, David. The Third Reich: Politics and Propaganda. London: Routledge, 2007. https://doi.org/10.4324/9780203930144

- Zec, Dejan. „Svakodnevni život u okupiranom Beogradu (1941-1944)“. Doktorska disertacija, Univerzitet u Beogradu, Filozofski fakultet, Odeljenje za istoriju, 2019.

RADE RISTANOVIĆ, PhD, Research Associate

Institute for Contemporary History

Belgrade, Republic of Serbia

raderistanovic@hotmail.com

\section{VERBAL DELICT, CITIZENS OF BELGRADE AND OCCUPATION REGIME DURING WORLD WAR II}

\section{Summary}

The intention of the occupation forces to close off the occupied territory to the flow of information that would prevent the citizens of Belgrade from being informed using other channels, experienced failure. The citizens of this city listened intensely to forbidden radio stations and transmitted information by word of mouth. Occupiers, collaborators, allies, resistance movements, and crimes in the NDH were dominant themes in Belgrade's illegal discourse. The emergence of national poets writing poems with a political connotation was entirely in accordance with the tradition of the Serbian people. We can see clearly that Belgrade restaurants, in this period, also served as a kind of news agency, where one could get all kinds of information or listen to banned songs. Markets, 
streets, and other places of gathering, where informal conversations were held, were sources where Belgrade citizens could get in touch with forbidden information. Individual examples of violations of a verbal delict, such as Aleksandar Ignjatović, a watchmaker and Leontina Kraus, a teacher, show that there were people among citizens who were not afraid of the repressive measures and threats by the occupation forces and who risked and lost their lives to defend the dignity of the occupied Serbian population.

From the very first day, the occupier emphasized that listening to banned radio stations and conducting anti-occupation propaganda would undergo severe punishment. Police and security institutions used a network of associates and police commissioners on the field to prevent this phenomenon and reveal the offenders. Many cases were also discovered on the base of information collected from denunciations. After the investigation, some of the arrested were shot, while others were put into concentration camps or got lighter sentences, which proves that the repressive system did not have unified punishment maintenance. Parallel with police operations, the occupier acted preventively using propaganda. This way the regime intended to intimidate those who spread forbidden news. The need for the implementation of these acts of repression and propaganda is a good example that proves that a lot of people listened to forbidden radio stations and violated verbal delict.

Despite the fact that listening to forbidden radio stations and violating the verbal delict was not in correlation with the achievement of military forces goals of the Allies, this kind of unarmed and civil resistance in Belgrade was of great importance. Firstly, we would like to emphasize its moral value. This kind of behavior represented the main defense against the intentions of the invader to crush fundamental values of a society, such as freedom of speech and the right to be informed. Anti-occupation rhetoric speeches compromised the regime and had negative influence on the tendency of the occupier to get the support of the domestic population by use of propaganda, which was one of preconditions for pacification and the exploitation of the occupied territory. Spontaneous spreading of news criticizing the occupier, accented victories of the Allies and defeats of the Wehrmacht were an equally important factor for the affirmation of organized resistance among the domestic population. Undoubtedly the listening of this news could influence the citizens of Belgrade to ,run to the woods“ and participate in organizations or support resistance movements as their sympathizers.

KEYWORDS: World War II, Belgrade, Propaganda, Censorship, Verbal Delict, Radio London, Repression, Civil Resistance 